\title{
TEKNOLOGI BUDIDAYA KEDELAI DENGAN PENDEKATAN PENGELOLAAN TANAMAN TERPADU (PTT) DI KABUPATEN KULON PROGO D.I. YOGYAKARTA
}

\author{
Suradal, Utomo Bimo Bekti dan Arif Anshori* \\ Balai Pengkajian Teknologi Pertanian Yogyakarta \\ *Corresponding author: arifanshori@yahoo.com
}

\begin{abstract}
Kulon Progo Regency is one producer of soybeans in D.I. Yogyakarta. The research aims to find out the result of soybean and farmers perception on soybean production technologies with an approach of integrated crop management (ICM) in Kulon Progo. The research was conducted in April-November 2013. 10 soybean varieties were planted to determine the level of productivity. Pattern and timing of planting explored through interviews with farmers and field inspections. Interviews were conducted with farmers to determine the perceptions of soybean production technology with the approach of integrated crop management (ICM) and in particular soybean varieties. The data were analyzed descriptively. The results showed in Kulon Progo Regency soybeans planted in irrigated land, rainfed lowland and upland, adjust the availability of water. The results showed in Kulon Progo Regency soybeans planted in irrigated land, rainfed lowland and upland, adjust the availability of water. Soybean production technology is not implemented by farmers as a whole, depends on the conditions of agro-ecosystems and agricultural inputs. In general, farmers agree with soybean production technology components with the approach of integrated crop management (ICM). Some farmers do not agree with the manufacture of drainage, mulching straw and harvest when $95 \%$ of the leaves have yellowed. Varieties Detam-2, Ijen and Tanggamus more adaptive and give higher yields. However, soybean farmers in Kulon Progo Regency prefer largely seeded soybean as Argomulyo and Burangrang. Gema varieties favored for short-lived.
\end{abstract}

Keywords: Integrated crop management; Kulon Progo; Soybean

Cite this as: Suradal, S., Bekti, U., \& Anshori, A. 2017. Teknologi Budidaya Kedelai dengan Pendekatan Pengelolaan Tanaman Terpadu (PTT) di Kab Kulon Progo D.I. Yogyakarta. Caraka Tani: Journal of Sustainable Agriculture. 32(1), 18-23. doi: http://dx.doi.org/10.20961/carakatani.v32i1.15902

\section{PENDAHULUAN}

Pemerintah Kabupaten Kulon Progo berupaya mendukung peningkatan produksi kedelai nasional. Produktivitas kedelai di Kab. Kulon Progo rata-rata 1,4 ton/ha (BPS, 2014), sehingga produksi kedelai masih banyak bergantung kepada luas areal tanam. Teknologi produksi di Kab. Kulon Progo sudah mampu menghasilkan 1,5 - 2,8 ton/ha (Anshori et al., 2012) memberikan peluang peningkatan produksi melalui perbaikan teknologi produksi.

Teknologi budidaya kedelai dapat menjadi terobosan untuk mengatasi produktivitas kedelai yang masih rendah. Teknologi budidaya spesifik lokasi menyesuaikan kondisi biofisik lahan, sosial ekonomi dan kelembagaan petani. Teknologi budidaya menggunakan pendekatan Pengelolaan
Tanaman Terpadu, yang dapat diterapkan di wilayah penghasil kedelai, baik di lahan sawah maupun tegalan. Teknologi yang telah dihasilkan diharapkan dapat diterima oleh petani, lebih jauh terjadi peningkatan produksi kedelai.

Kabupaten Kulon Progo merupakan salah satu penghasil kedelai di D.I. Yogyakarta. Teknologi budidaya kedelai dengan pendekatan pengelolaan tanaman terpadu (PTT) diterapkan di Kabupaten Kulon Progo melalui Sekolah Lapang Pengelolaan Tanaman Terpadu (SL-PTT) kedelai. Petani yang tergabung dalam SL-PTT membentuk Sekolah Lapang (SL), dilengkapi dengan Laboratorium Lapang (LL) sebagai wahana belajar dan mencoba teknologi, diskusi teknologi dan pemecahan masalah secara berkala dan fasilitasi bahan bacaan yang terkait dengan pengelolaan tanaman terpadu (PTT). 
Prinsip pengelolaan tanaman terpadu (PTT) mencakup empat unsur yaitu integrasi, interaksi, dinamis dan partisipatif (Kementerian Pertanian, 2010). Komponen teknologi dalam pengelolaan tanaman terpadu (PTT) mencakup teknologi dasar yang bersifat relatif umum dan teknologi pilihan yang lebih bersifat spesifik lokasi (Departemen Pertanian, 2008).

Penelitian bertujuan untuk mempelajari teknologi budidaya kedelai dengan pendekatan pengelolaan tanaman terpadu (PTT), produktivitas dan persepsi petani dan secara khusus varietas unggul kedelai di Kabupaten Kulon Progo.

\section{METODE PENELITIAN}

Penelitian terhadap hasil dan persepsi petani terhadap teknologi budidaya kedelai dengan pendekatan pengelolaan tanaman terpadu (PTT) dilaksanakan di Kecamatan Nanggulan, Galur dan Sentolo Kabupaten Kulon Progo D.I. Yogyakarta pada bulan April-Nopember 2013. Metode survei digunakan untuk mengetahui pola dan waktu tanam serta persepsi petani terhadap teknologi budidaya kedelai dengan pendekatan pengelolaan tanaman terpadu (PTT) dan secara khusus varietas unggul kedelai di tiga (3) Kecamatan di Kabupaten Kulon Progo. Wawancara dilakukan terhadap 10 orang petani kunci. Percobaan lapang dilakukan untuk memperkenalkan 10 varietas unggul kedelai dengan menerapkan teknologi budidaya kedelai dengan pendekatan pengelolaan tanaman terpadu (PTT). Analisis data dilakukan secara deskriptif (Creswell, 2010).

\section{HASIL DAN PEMBAHASAN}

\section{Pola Tanam di Kabupaten Kulon Progo}

Kedelai ditanam di lahan sawah ataupun tegalan dengan menyesuaikan kondisi pola tanam setempat, yang sangat dipengaruhi oleh kondisi iklim. Dalam praktek, keberhasilan usaha tani kedelai sangat ditentukan oleh ketepatan waktu tanam. Pada daerah tadah hujan, ketepatan pemilihan waktu tanam menghindarkan kedelai dari bahaya kekeringan atau cekaman air serta gangguan hama dan penyakit. Pada daerah irigasi, pengaturan air mutlak diperlukan menyesuaikan kebutuhan air tanaman. Kementerian Pertanian (2011) menyebutkan bahwa pada lahan sawah, kedelai umumnya ditanam pada musim kemarau setelah tanam padi. Pada lahan tegalan kedelai umumnya ditanam pada musim hujan.

Kedelai sangat peka terhadap lingkungan tumbuh, sehingga ketidaktepatan waktu tanam dapat menurunkan hasil atau lebih jauh gagal panen. Kecukupan air sangat diperlukan pada masa awal tumbuh, berbunga dan pengisian polong. Selain itu, saluran drainase diperlukan untuk membuang kelebihan air. Dalam masa pertumbuhan sampai mendekati panen, hama dan penyakit kedelai sangat beragam.

Di Kabupaten Kulon Progo, kedelai tidak ditanam secara serempak, menyesuaikan dengan kondisi pola dan waktu tanam, lingkungan atau agroekosistem setempat. Visualisasi pola dan waktu tanam di Kabupaten Kulon Progo dapat dilihat pada gambar 1 .

Lahan pertanian di Kabupaten Kulon Progo terdiri atas sawah irigasi, sawah tadah hujan dan tegalan. Gambar 1, menunjukkan rerata bulanan curah hujan di Kabupaten Kulon Progo (Kecamatan Sentolo) tahun 2003-2012, dengan curah hujan tahunan sebesar $1.468 \mathrm{~mm}$. Di lokasi terdapat 3 bulan basah $(>200 \mathrm{~mm})$ antara bulan Desember-Pebruari dan 6 bulan kering $(<100$ $\mathrm{mm}$ ) antara Mei-Oktober.

Pada lahan sawah irigasi pola dan saat tanam ditentukan oleh ketersediaan air irigasi. Musim tanam ke-1, sekitar bulan Desember-Maret, petani menanam padi. Kedelai ditanam pada musim tanam ke-2 setelah padi pada bulan AprilMei. Pada lahan sawah tadah hujan dan tegalan, petani menanam menyesuaikan curah hujan. Kondisi ini dilakukan oleh sebagian petani Kecamatan Nanggulan, Girimulyo dan Kalibawang serta sebagian petani daerah tinggi yang tidak terjangkau irigasi. Kedelai sebagian besar ditanam pada musim tanam ke-2, dengan menyesuaikan kondisi ketersediaan air. 


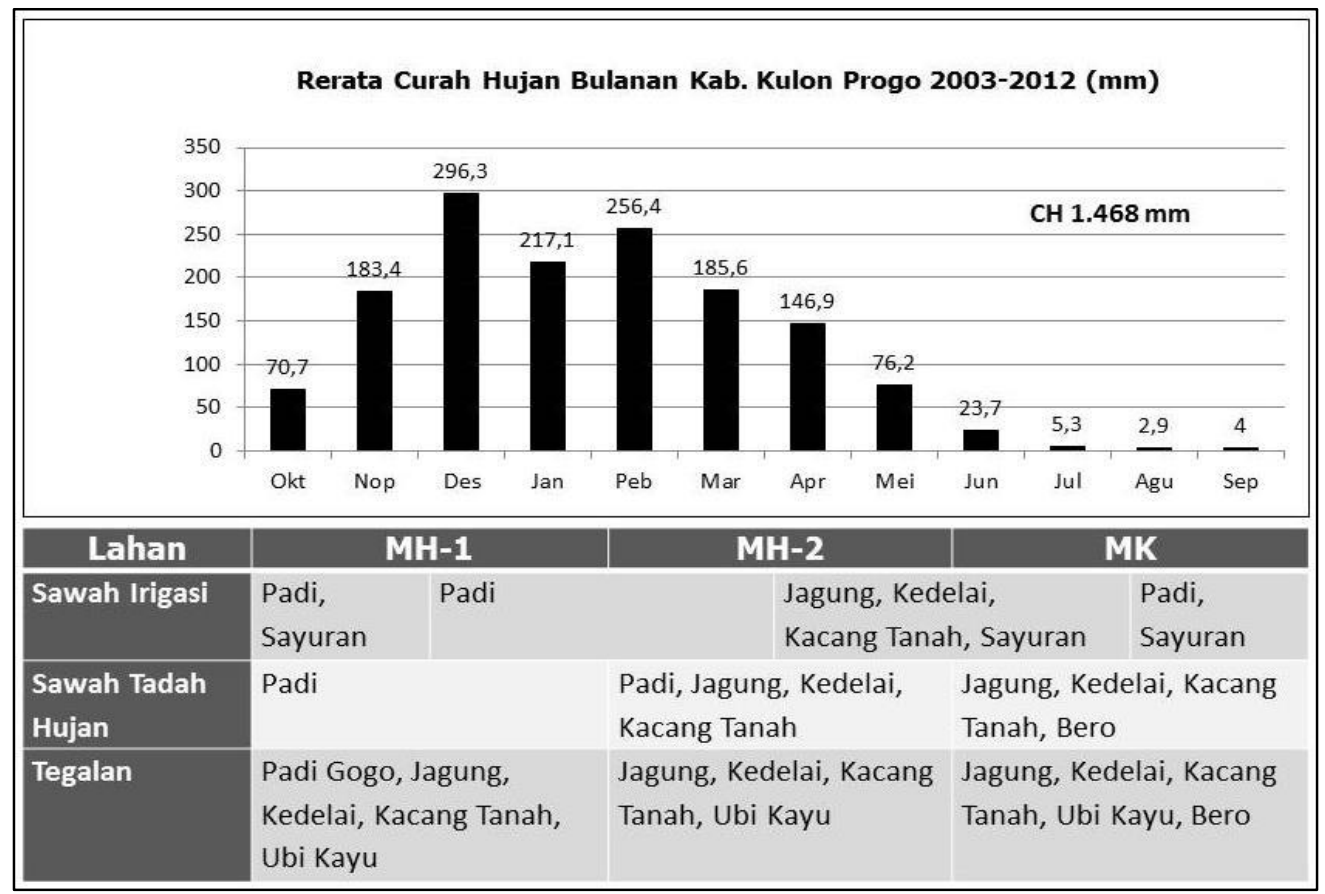

Gambar 1. Rerata Curah Hujan Bulanan Tahun 2003-2012 di Kabupaten Kulon Progo (Kecamatan Sentolo) dan Kaitannya dengan Pola Tanam Sebagian Besar Petani

\section{Teknologi Budidaya Kedelai dengan} Pendekatan PTT di Kabupaten Kulon Progo

Prinsip utama penerapan PTT adalah pendekatan inovatif dalam upaya meningkatkan produktivitas usahatani melalui perbaikan perakitan paket teknologi yang sinergis antar komponen teknologi, dilakukan secara partisipatif oleh petani dan bersifat spesifik lokasi (Marwoto et al., 2009). Teknologi produksi kedelai untuk setiap tipe lahan (lahan sawah irigasi, lahan sawah tadah hujan, lahan kering) telah teruji dan mampu memberikan hasil lebih dari 2 t/ha dan meningkatkan keuntungan usaha tani (Adisarwanto et al., 2007).

Tabel 1. Teknologi Budidaya Kedelai dengan Pendekatan PTT di Kabupaten Kulon Progo D.I. Yogyakarta

\begin{tabular}{|c|c|c|}
\hline No. & Komponen Teknologi & Diperkenalkan \\
\hline \multicolumn{3}{|c|}{ Teknologi Dasar } \\
\hline 1. & Varietas Unggul Baru & $\begin{array}{l}\text { Argomulyo, Burangrang, Detam-1, Detam-2, Gema, Gepak } \\
\text { Kuning, Ijen, Panderman, Tanggamus, Wilis }\end{array}$ \\
\hline 2. & Benih & Bermutu dan Berlabel, daya berkecambah $>80 \%$ \\
\hline 3. & Saluran Drainase & $3-4$ meter ; 20 × $30 \mathrm{~cm}$ \\
\hline 4. & Pengaturan Populasi Tanaman & Jarak tanam $40 \times 20 \mathrm{~cm}, 2-3$ benih per lubang \\
\hline 5. & Pengendalian OPT & Prinsip-prinsip PHT \\
\hline \multicolumn{3}{|c|}{ Teknologi Pilihan } \\
\hline 1. & Penyiapan Lahan & Tanpa olah tanah ; Tugal \\
\hline 2. & Pemupukan & NPK $200 \mathrm{~kg} / \mathrm{ha}$, pupuk daun \\
\hline 3. & Pemberian Pupuk Organik & 2 ton/ha sebelum tanam padi pada $\mathrm{MH}-1$, atau saat tanam \\
\hline 4. & Pengairan Periode Kritis & Irigasi 2-3 minggu sekali atau sesuai kebutuhan masa kritis \\
\hline 5. & Panen dan Pascapanen & 95\% polong coklat dan daun berwarna kuning \\
\hline
\end{tabular}

Pendekatan pengelolaan tanaman terpadu kedelai membagi komponen teknologi produksi menjadi teknologi dasar dan pilihan. Komponen teknologi dasar sangat diharapkan dapat diterapkan di semua wilayah pertanaman kedelai. Komponen teknologi pilihan diterapkan sesuai 
dengan kondisi, kemauan dan kemampuan petani. Komponen teknologi, baik dasar maupun pilihan, diterapkan saat perencanaan, penataan tanaman, pengelolaan hara, pemeliharaan tanaman dan panen serta pasca panen. Komponen teknologi PTT kedelai di Kabupaten Kulon Progo, yang dihasikan secara partisipatif dengan melibatkan petani, dapat dilihat pada Tabel 1.

Tahap perencanaan penanaman kedelai terdiri tiga komponen teknologi yaitu varietas unggul, benih bermutu-berlabel dan penyiapan lahan. Varietas unggul dan benih bermutu-berlabel merupakan komponen teknologi dasar yang berpotensi dapat diterima dan diadopsi petani. Penyiapan lahan merupakan komponen teknologi pilihan yang akan ditentukan oleh kondisi sumberdaya setempat. Di Kabupaten Kulon Progo petani menanam kedelai dengan sistem tugal dan tanpa olah tanah.

Penataan tanaman terdiri atas dua komponen teknologi dasar, yaitu pembuatan saluran drainase dan pengaturan populasi tanaman. Benih ditanam dengan jarak tanam $40 \times 20 \mathrm{~cm}, 2-3$ benih per lubang. Saluran drainase berdimensi $20 \times 30 \mathrm{~cm}$, berjarak 3-4 meter, menyesuaikan kondisi dan sifat tanah.

Pemupukan anorganik dan pemberian bahan organik merupakan dua komponen teknologi pilihan dalam pengelolaan hara. Pupuk organik 2 ton/ha diberikan sebelum tanam padi pada MH-1 atau sebelum tanam kedelai. Lubang tanam ditutup dengan pupuk organik. Pemupukan NPK diberikan pada saat kedelai berumur 10-15 hari dengan dosis $200 \mathrm{~kg} / \mathrm{ha}$. Pupuk daun diberikan sebagai pelengkap.

Pemeliharaan tanaman berupa pengairan pada dan pengendalian organisme pengganggu tanaman secara terpadu. Air diberikan saat pembungaan dan pengisian polong, atau setiap 23 minggu sekali dengan tetap memperhatikan kondisi kelengasan tanah. Pengendalian organisme pengganggu tanaman secara terpadu mencakup identifikasi jenis penyakit, menentukan tingkat kerusakan tanaman, taktik dan teknik pengendalian yang mengusahakan tanaman selalu sehat, penggunaan varietas tahan, pengendalian hayati, pengendalian secara fisik dan mekanis serta pilihan terakhir dengan penggunaan pestisida kimia (fungisida, bakterisida, insektisida). Pengendalian gulma dilakukan secara manual dengan pendangiran dan pencabutan.

Panen dilakukan pada saat tanaman sudah masak. Umur panen kedelai ditentukan oleh jenis varietas, musim tanam, kelengasan tanah serta perlakuan agronomis, umumnya 70 - 90 hari. Kedelai masak ditandai dengan $95 \%$ polong berwarna coklat atau daun sudah berwarna kuning. Pasca panen kedelai meliputi penjemuran brangkasan kedelai sampai kondisi kering, pemisahan biji dari kulit kedelai, pembersihan dari kotoran dan penyimpanan biji.

\section{Produktivitas dan Persepsi Petani terhadap Varietas Unggul Kedelai di Kabupaten Kulon Progo}

Di Kabupaten Kulon Progo, referensi petani tentang varietas unggul kedelai masih rendah. Beberapa varietas sudah dikenal petani secara luas diantaranya adalah Wilis dan Grobogan. Varietas Wilis dikenal luas petani karena pernah ditanam masal di Kabupaten Kulon Progo. Varietas Grobogan dikenal karena sering digunakan sebagai varietas unggul dalam SL-PTT kedelai.

10 varietas unggul kedelai ditanam pada tahun 2013 di Kabupaten Kulon Progo. Di samping pengenalan varietas, diharapkan dapat diketahui tingkat adaptasi. Varietas tersebut adalah Argomulyo, Burangrang, Detam-1, Detam-2, Gema, Gepak Kuning, Ijen, Panderman, Tanggamus dan Wilis. Produktivitas 10 varietas unggul kededai di Kabupaten Kulon Progo dapat dilihat pada gambar 2.

Penanaman varietas unggul kedelai dilaksanakan di 3 kecamatan, yaitu Kecamatan Nanggulan, Galur dan Sentolo, pada lahan sawah irigasi, ditanam pada $\mathrm{MH}-2$ bulan April-Juli 2013. Produktivitas kedelai di Kecamatan Nanggulan lebih tinggi dari pada Kecamatan Galur dan Sentolo, dengan kisaran 16, 16-26, 40 $\mathrm{ku} / \mathrm{ha}$. Di Kecamatan Nanggulan, produktivitas varietas Detam-2, Ijen dan Tanggamus melebihi $25 \mathrm{ku} / \mathrm{ha}$. Produktivitas dihitung berdasarkan berat biji kering hasil ubinan 2,5 x 2,5 meter (tanpa faktor koreksi). 


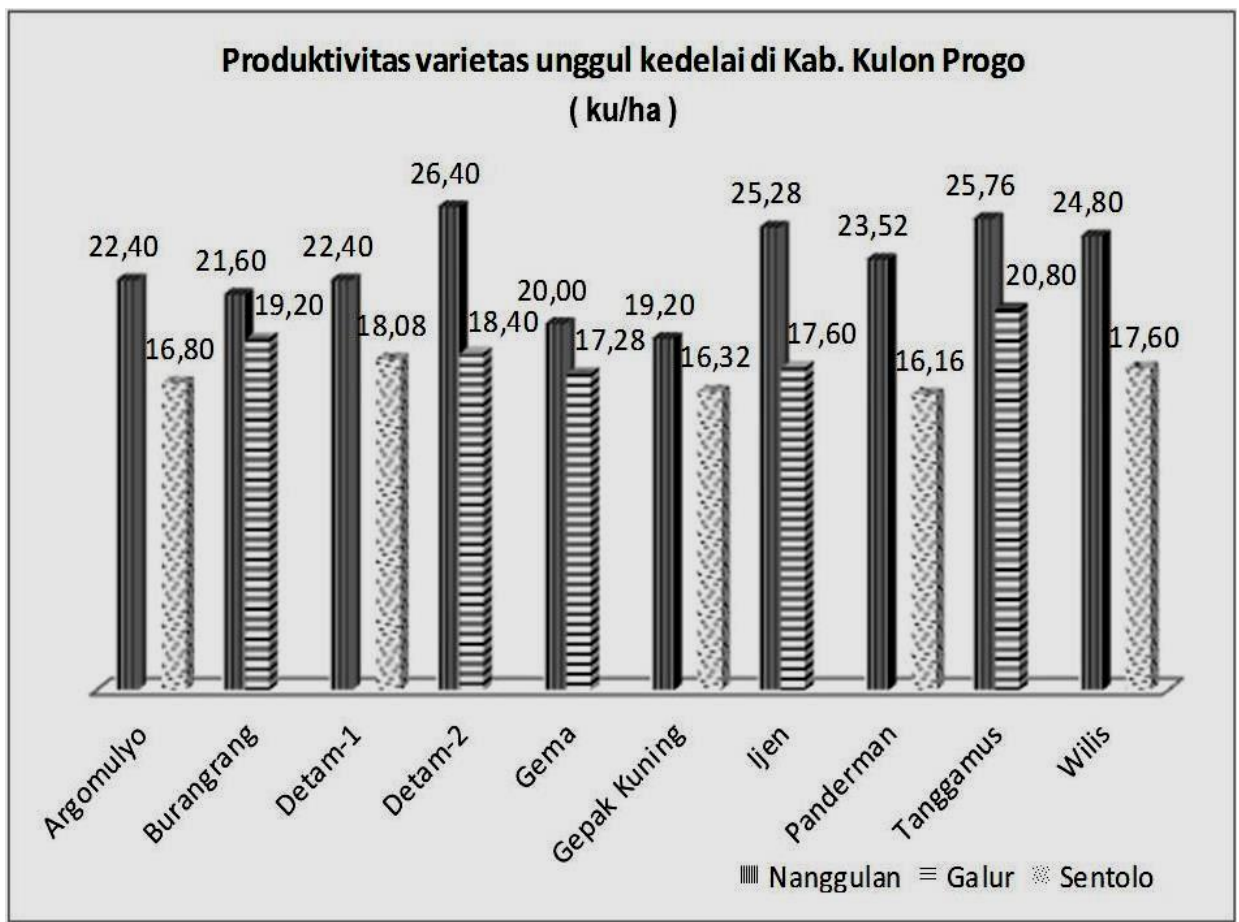

Gambar 2. Produktivitas (ku/ha) Varietas Unggul Kedelai di Kabupaten Kulon Progo Tahun 2013

Varietas unggul kedelai mempunyai sifat beragam terkait dengan ukuran biji, umur panen, potensi hasil, warna biji, daya tahan terhadap cekaman biotik atau abiotik serta daya adaptasi. Pemahaman petani terhadap sifat varietas unggul kedelai berpengaruh terhadap kesukaan dan pilihan varietas. Tabel 2 menunjukkan pandangan petani terhadap beberapa varietas unggul kedelai yang telah ditanam dan memberikan hasil.

Tabel 2. Respon Petani Kabupaten Kulon Progo terhadap Varietas Unggul Baru Kedelai

\begin{tabular}{lccccc}
\hline \multicolumn{1}{c}{ Varietas } & Suka & Kurang Suka & $\begin{array}{c}\text { Tidak Suka } \\
\text { Persentase }(\%)\end{array}$ & Tidak Tahu & Jumlah \\
\hline Argomulyo & 100 & - & - & - & 100 \\
Burangrang & 100 & - & - & - & 100 \\
Detam-1 & 50 & 10 & 40 & - & 100 \\
Detam-2 & 50 & 10 & 40 & - & 100 \\
Gema & 90 & 10 & - & - & 100 \\
Gepak Kuning & 50 & 10 & 40 & - & 100 \\
Ijen & 50 & 10 & 40 & - & 100 \\
Panderman & 85 & 15 & - & - & 100 \\
Tanggamus & 90 & 10 & - & - & 100 \\
Wilis & 90 & 10 & - & - & 100 \\
\hline
\end{tabular}

Produktivitas tinggi ditunjukkan oleh varietas Detam-2, Ijen dan Tanggamus. Namun demikian, petani kedelai Kabupaten Kulon Progo lebih menyukai varietas yang berbiji besar, yaitu Argomulyo dan Burangrang. Kedelai hitam kurang disukai karena memerlukan pemasaran khusus, biasanya diserap oleh industri/ perusahaan. Tanggamus dan Wilis disukai karena mempunyai produktivitas tinggi, walaupun berbiji sedang. Gema disukai karena umurnya yang sangat pendek.

\section{Persepsi Petani terhadap Teknologi PTT Kedelai di Kabupaten Kulon Progo}

Komponen teknologi produksi kedelai dengan pendekatan PTT yang diterapkan di Kabupaten Kulon Progo dihasikan secara partisipatif dengan melibatkan petani. Namun, petani memiliki 
persepsi beragam terkait dengan komponen teknologi tersebut. Persepsi petani terhadap komponen teknologi PTT kedelai dapat dilihat pada Tabel 3.

Tabel 3. Persepsi Petani Kabupaten Kulon Progo terhadap Teknologi PTT Kedelai

\begin{tabular}{lccccc}
\hline \multirow{2}{*}{ Teknologi PTT kedelai } & Setuju & Kurang Setuju & Tidak setuju & Tidak Tahu & Jumlah \\
\cline { 2 - 6 } & \multicolumn{5}{c}{ Persentase $(\%)$} \\
\hline Varietas unggul baru & 100 & - & - & - & 100 \\
Benih bermutu dan berlabel & 100 & - & - & - & 100 \\
Saluran drainase & 70 & 20 & 10 & - & 100 \\
Jarak tanam & 100 & - & - & - & 100 \\
$2-3$ biji per lubang & 100 & - & - & - & 100 \\
Pengendalian gulma terpadu & 90 & 10 & - & - & 100 \\
Pengendalian hama terpadu & 100 & - & - & - & 100 \\
Pengendalian penyakit terpadu & 100 & - & - & - & 100 \\
Mulsa jerami & 30 & 20 & 50 & - & 100 \\
Tanam tugal & 100 & - & - & - & 100 \\
Pemupukan sesuai kebutuhan & 100 & - & - & - & 100 \\
Pemberian pupuk organik & 100 & - & - & - & 100 \\
Pengairan pada periode kritis & 90 & 10 & - & - & 100 \\
Panen saat 95\% daun kuning & 90 & 10 & - & - & 100 \\
Tebal pengeringan biji 25 cm & 100 & - & - & - & 100 \\
\hline
\end{tabular}

Pembuatan saluran air setiap $3-4 \mathrm{~m}$, pengendalian gulma terpadu, mulsa jerami, pengairan pada periode kritis dan panen saat 95\% daun kuning merupakan komponen teknologi yang tidak sepenuhnya disetujui oleh petani. Saluran drainase setiap jarak 3 - 4 meter, dianggap mengurangi luas lahan yang ditanami. Mulsa jerami terkendala kebutuhan jerami untuk pakan ternak. Pada dasarnya petani menyetujui komponen teknologi pengelolaan tanaman terpadu (PTT) kedelai, namun karena beberapa pertimbangan belum bisa diterapkan secara utuh.

\section{KESIMPULAN}

Varietas unggul kedelai Burangrang dan Argomulyo disukai petani Kabupaten Kulon Progo. Komponen teknologi produksi kedelai dengan pendekatan PTT harus diterapkan secara selektif sesuai dengan kondisi sumberdaya, kemauan dan kemampuan petani.

\section{DAFTAR PUSTAKA}

Adisarwanto, T., Subandi, \& Sudaryono. 2007. Teknologi Produksi kedelai. Hal: 229-252. Dalam: Sumarno, et al. (penyunting). Kedelai: Teknik Produksi dan Pengembangan. Puslibangtan Bogor.
Anshori, A., Srihartanto, E., \& Mulyadi. 2012. Teknologi budidaya kedelai spesifik lokasi di D.I. Yogyakarta. Balai Pengkajian Teknologi Pertanian Yogyakarta.

BPS (Badan Pusat Statistik) Kulon Progo. 2014. Kulon Progo dalam angka.

Creswell, J.W. 2010. Research Design: Pendekatan kualitatif, kuantitatif dan mixed. Yogyakarta: Pustaka Pelajar.

Departemen Pertanian. 2008. Panduan Pelaksanaan Sekolah Lapang Pengelolaan Tanaman Terpadu (SL-PTT) Kedelai. Departemen Pertanian. Jakarta

Kementerian Pertanian. 2010. Pedoman Umum PTT Kedelai.

Kementerian Pertanian. 2011. Teknologi Produksi Kedelai, Kacang Tanah, Kacang Hijau, Ubi Kayu dan Ubi Jalar. Kementerian Pertanian. Jakarta.

Marwoto, Subandi, T. Adisarwanto, Sudaryono, A. Kasno, S. Hardaningsih, D. Setyorini, \& M.M. Adie. 2009. Pedoman Umum PTT kedelai. Badan Litbang Pertanian. Jakarta. 